\title{
Rescue of the Remnants: The British Emergency Medical Relief Operation in Belsen Camp 1945
}

\author{
E Trepman
}

\begin{abstract}
The British Army liberated the German concentration camp at Belsen on April 15,1945 . The thousands of inmates (estimates range from 60,000 to 78,900 inmates), mostly Jews from eastern Europe, were dying at a rate of 500-600 per day from disease, and many more were being killed by the German guards and co-workers. Diseases prevalent included typhus, tuberculosis, nutritional and infective diarrhoea, severe malnutrition and starvation, and others. Despite huge obstacles including the ongoing war effort, shortages of supplies, and limited numbers of workers, a relief operation was rapidly organized to control the typhus epidemic and salvage as many inmates as possible. The 10,000 emaciated corpses which had been lying all over the camp were collected and buried in mass graves. Inmates were disinfected with D.D.T., scrubbed in a "human laundry," and evacuated from the typhus-ridden Horror Camp (Camp 1) to a hospital organized in the barracks of the Panzer Training School (Camp 2). Feeding of the inmates was carefully regulated, and some basic medical treatment organized. The relief operation was performed by British Army units, detachments of the British Red Cross, British and Belgian medical students, and other volunteers including those from among the less debilitated inmates. Although 13,000 inmates died after the liberation despite the relief operation, thousands of others were rescued.
\end{abstract}

Key words:

Concentration camp, Typhus, Tuberculosis, Diarrhoea, Starvation, Genocide, Germany, World War II, Holocaust

Elly Trepman MD, Associate Professor, Section of Orthopaedic Surgery,

Department of Surgery, University of Manitoba, GF307 -820 Sherbrook Street,

Winnipeg, Manitoba, Canada R3A 1R9

\section{The Liberation Of Belsen Camp}

On April 12, 1945 two German messengers notified the oncoming British Army that there was a concentration camp at Belsen with 60,000 "political" prisoners, among which, they claimed, were 1500 cases of typhus $(1,2), 900$ of typhoid fever, and others with various illnesses (1). However, when units of the British Army (14 Amplifier Unit of the Intelligence Corps, followed by
63 Anti-Tank Regiment, Royal Artille高) entered Belsen Camp on April 15 (3,4), the found that the condition of the prisoners was far worse than what had been forewarned. $9 n$ the part of Belsen known as Camp 1, a halPa square mile area (5) which the Britiogh liberators referred to as the "Horror Cam 9 ", (6), they found an estimated $22,000-28,1$ 通 women $(1,3,7), 18,000$ men, and 5 है children packed into approximately 1 to wooden huts $(7,8,9)$ divided into five mainh compounds, three for men and two far women (1). The huts were approximately 110 feet by 30 feet in size, and eagh contained from 400 to 800 inmates $(3,5)$. In the brick buildings of Camp $2(7,8)$, whig had been previously used as the Pan $\mathbb{B}_{\mathrm{S}} \mathrm{r}$ Training School (10) and as housing for S $\mathrm{S}$. and Wehrmacht troops (1), an estimatơd $17,000-27,000$ male prisoners were held $\&$, 8) including 15,000 men who had been brought five days earlier from the V1 facto $y$ at Dora Camp near Nordhausen (3). Tơ large majority of prisoners in Camps 1 anळू2 were Jews from Poland and the Soviet Uni@ (including the Baltic countries, particulaz̋y Lithuania), transported to Germany from concentration camps such as Auschwi Majdanek, and Stutthof during the Soviet advance westward, as well as others fro Czechoslovakia, Belgium, France, Italy, agid Yugoslavia $(7,8)$.

Lieutenant Colonel JAD Johnston, RAM of 32 Casualty Clearing Station (CCS) (1 $\overrightarrow{\mathrm{P}}$, who was appointed Senior Medical Office (SMO) of Belsen Camp (12, 13, 13), reported on April 18, one day after 蕞 entered the camp $(7,12,13,14)$ :

"It is impossible to give an adequat? description on paper. Camp 1. - A dense. mass of emaciated apathetic scarecrows huddled together in wooden huts withoun beds or blankets in many cases, without and clothing whatsoever in some cases. The females in worse condition than the meno their clothing generally, if they have any, only filthy rags. The dead lie all over the camp and in piles outside the blocks of hut: which house the worst of the sick and ares

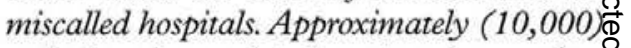
naked and emaciated corpses in various stages of decomposition are lying about this camp. Sanitation is non-existent. Pits with 응 in only a few instances, wooden perch rails. are available in totally inadequate numbers,,$\frac{}{\rightleftharpoons}$ but the majority of inmates, from starvation, 
apathy, and weakness, defaecate and urinate where they sit or lie, even inside the living huts. There is no running water or electricity. All water is being brought in by our water trucks." (7).

The approximately 10,000 "dead lay in naked walls of bodies around the huts, many of which were filled, literally filled, with the dead and the dying" $(3,7)$. They lay crowded on bunks or on the floor, "in foul rags drenched in excreta, covered with lice" (7). Of the 40,00069,000 prisoners in Camp 1, 500-600 were dying daily from disease (over 1000 on one day in March 1945 (15)), and many more were being killed by the German guards (7, 16); on April 15 the death toll was 800 (3). There had been almost no water for a week prior to the liberation (7) because of "the Germans cutting the water-supply as a final gesture before they left" (8), and no food or water had been provided for four or five days before the British Army arrived (8).

\section{Organization Of The Relief Operation}

The British 11th Armoured Division entered Belsen Camp on April 15 at midday, and by 4 p.m. the medical relief work was begun by the Divisional Field Hygiene Section (17). The Divisional ADMS Col D Bluett immediately arranged for supplies of AL63 and disinfectant, and thus 15,000 inmates were deloused during the first three days after the liberation (17). The Deputy Director of Medical Services, Second Army, Brigadier HL Glyn Hughes, who personally inspected the camp on April $15(3,4)$, ordered five British medical units to Belsen which arrived on April $17(1,7)$, and several days later these were reinforced with three additional medical units, thus beginning "the colossal medical task of transforming a deathtrap into a hospital" (7). This rescue operation required the diverting of these units from the ongoing military campaign (2), and although it "could not be regarded as a commitment which came strictly under the Army Medical Services... the dictates of humanity required quick action" (7). Even after the full establishment of the British Military Government, which assumed responsibility for the Displaced Persons in the concentration camps in

Table 1. Belsen Camp: Urgent measures to be taken. *

(a) Bury dead

(b) Evacuate patients in Camp I to suitable clean buildings in Camp II, with plans for reception, delousing and cleaning.

(c) Evacuate fit from Camp I to Camp II.

(d) DDT all inmates.

(e) Arrange suitable feeding for patients. Death-rate has increased since abundant food became available.

(f) Pile and burn masses of rubbish, rags and human excreta which litter the camp.

* From report of Lieutenant Colonel FAD fohnston, $R A M C$, the Senior Medical Officer (SMO) of Belsen Camp, April 18, $1945(13,14)$
British-occupied Germany of which Belsen was the largest, the Army Medical Services $\longrightarrow$ continued to provide large-scale medical assistance because the Military Government 3 had only a "skeleton staff" without adequate $\underset{\complement}{\mathbb{Q}}$ material resources, equipment, or personnelᄋ for the task (18).

Johnston's report of April 18 included a list $\stackrel{\text { ? }}{.}$ of proposed urgent measures, which became $\overrightarrow{\vec{F}}$ the plan of action for the first few weeks ofo the rescue operation $(13,14)$ (Table 1). On April 18 the British forced the German S.S. $\frac{\overline{\bar{p}}}{\overline{0}}$ and Hungarian guards at gunpoint, assisted $\varnothing$ by trucks and bulldozers, to collect and bury» the thousands of dead bodies in mass graves $\vec{O}$ and to clean up the filth $(4,7,19)$. Under the direction of Johnston, a hospital of $17,000 \vec{\omega}$

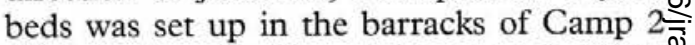
(7) including the Round House, a building Эّ which had been the S.S. officers' mess hall? $(10,16)$. All inmates from the typhus-ridden Horror Camp (Camp 1) were evacuated to the Camp 2 hospital, at a rate of 700-1500' per day $(3,4,20,21)$; the first 500 typhus? cases were evacuated on April 18 (3).

The evacuation of Camp 1 consisted of $\vec{O}$ four steps: calling the inmates out of their? blocks, registration, bathing and disinfection, and embussing on lorries to Camp 2(3). The inmates were processed 20 at a time in aᄋ "human laundry" which was set up in a.former horse stable near the entrance too Camp 2 (21). Here they were "placed on slabs, scrubbed down to remove the caked dirt and faeces of months and dusted with DDT,' $\left(7, \frac{\circ}{\mathbb{\infty}}\right.$ $8,20,21,22)$ the newly developed insecticide which had recently been usedô successfully to kill mosquitoes and prevent malaria during the Italian campaign (23) The delousing of the entire population of 40,000 inmates with DDT (7) was completed by April 30, just two weeks after地 the liberation (8). Despite this, numerous healthier inmates waiting to be evacuated災 from Camp 1 contracted infections and died, including those who were helping in the relief effort (3). By May 18 the evacuation of Camp 1 was completed, and 13,834 patients had been admitted to the Camp 2 hospitalo (8). Although accurate numbers were impossible because of the enormity of the problem and the utter chaos present, it was N estimated that a total of 78,900 inmates had been evacuated from Camp 1, and that 23,000 dead had been buried, including the $e_{\sigma}^{\omega}$ 10,000 corpses that were found unburied on April 15 and 13,000 that had died after the्⿱ liberation because of disease and starvation (22). By the end of May, 30,000 living 0 inmates remained in Belsen, includinge 11,200 to 13,000 in the main hospital area? $(3,7)$.

The practical problem of organizing such $\underset{2}{2}$ colossal rescue operation was enormous. Ifo was necessary to find beds, bedsheets? medication, dressings, and other necessitieş्亏 which were scarce after the liberation (7)? 
Large supplies of drugs and dressings were captured from the Germans(1, 3). German military medical stores were collected into central dumps, such as the large dump at Celle near Belsen where nearly 2000 tons of medical equipment were concentrated, sorted, and issued to the Belsen hospital areas and other Allied ex-prisoner of war and German military hospitals (2). Captain Leslie Hardman, the Jewish Chaplain of 8 Corps, obtained tinned and fresh milk, porridge, peas, rice, and other foodstuffs from Red Cross parcels by requisitioning and appealing (3). The physician in charge of hospital stores at Belsen, Capt "Frosty" Winterbottom, RAMC, equipped 7000 beds in one week by 'ffreezing' all he could lay hands upon" in the district around Belsen (13). In addition, Winterbottom organized thousands of sets of clothing and footwear for the liberated prisoners, a hairdressing salon, a group of plumbers and carpenters for the hospital buildings, internee seamstresses who mass-produced the "standard Belsen nightie" for the sick, and a workshop for wirelesses and bicycles (13). $\mathrm{He}$ also organized a night club - "The Coconut Grove" - "chiefly for rehabilitating the patients" $(10,13)$. A former stable in Camp 2 was converted to an issue store for clothing requisitioned from German townships miles around Belsen, and was named "Harrod's" (3). However, by early May German medical supplies were short, and stocks of some essential items were exhausted because the medical resources of the British Army Medical Services were "fully stretched" in dealing with the heavy commitments at Belsen as well as to the inmates of other concentration camps, British troops, and Allied ex-prisoners of war $(2,18)$.

Approximately 3000 British troops were directly involved in the relief effort in Belsen (3). Nursing and domestic help was organized from liberated prisoners who were strong enough to work, and also from the German population (7). Furthermore, in response to an appeal from the military, six detachments of British Red Cross workers arrived on April 23 to help nurse the sick and evacuate them from Camp 1 via the "human laundry" to the Camp 2 hospital $(4,7)$. One week later, a group of 95-100 medical students arrived from London, who helped with the huge job of cleaning and feeding the weak inmates, and also provided medical help $(3,7,16,24,25)$. The students took over the major job of feeding the starving inmates in Camp $1(3,7,16,26,27)$. Forty tons of dried milk and protein hydrolyzate were delivered (7). Within 10 days of arrival of the students, the daily death rate dropped from 300-500 per day in half (24), and subsequently to 60 per day in mid May (7). The British nursing services also had a major role in the transformation of Belsen during the weeks after the liberation (28).
As the evacuation of Camp 1 was nearingo completion, the barracks were burned dow to prevent further spread of the typhu疋 epidemic. The last of the huts of Camp 1 was destroyed in a ceremony on May $21\left(3,4,5 \frac{\pi}{8}\right.$ $13,19,21,22)$. Mid May in the Camp \& hospital, there remained 11,200 patients iro the main hospital area and 2300-3500 sick in: another area (7). Each square of Camp $\overrightarrow{\overrightarrow{2}}$ accomodated approximately 700 patients irg five barracks under the direction of on medical officer from the RAMC and one of two British nurses; each of the barrack $\mathbb{\otimes}$ housed approximately 150 patients under thळ care of one Swiss internee, or Germarb doctor, assisted by internee or German nurses (7). Acute surgical cases, both majof and minor, were treated in the Camp hospital area including the Round Hous] hospital $(5,10)$. Anaesthesia with pentothal, open ether, or ethyl chloride wast administered by the medical students (5). $\quad \dot{\omega}$

Camp 3 at the village of Bergen (10) was g convalescent area of 20 barrack buildings (3)o with 8000 inmates (7) who were not as critically ill as those in Camps 1 and 2, buio who were weak and susceptible to disease. $\mathrm{A}_{\tilde{O}}^{\stackrel{0}{0}}$ typhus epidemic broke out in Camp 3 in mid吕 May which necessitated the transfer of sick tơ the Camp 2 hospital $(7,13)$. A group of smaller barracks of former German officers' quarters, known as Camp 4, was also used to house healthier surviving inmates(3).

The policy adopted by the British relien administration at the beginning of the rescue operation was to attempt to save the greatest number of prisoners using a program of triage. The prisoners who had "a reasonable chance of survival" were treated with suitable feeding and hygienic measures to prevent $\widehat{3}$ further infection, whereas the most sick were provided with bedrest and elementary nursing (8). One of the medical students, who had requested that one of his patients be transferred, was advised by the' administrative officer that "to treat these people. individually is a great mistake... When anô ambulance calls at your hut, the sick will be taken to hospital. Until then you must wait. It is음 folly to waste time on one patient" (29). This student was angered by "the continual sense of frustration" which is natural for a physiciano who is accustomed to giving the individual 0 patient the utmost priority(29). Despite the N administrative emphasis on mass treatment, which was dictated by the mammotho numbers of sick and starving, acuteness of the medical and epidemic emergency, and limited resources available, the experiences ${ }_{0}^{\circ}$ of individual prisoners left a deep impression on the relief workers, especially the medical students (30).

However, some individual care was provided to critically ill inmates in theo Horror Camp. As the evacuation of inmates from Camp 1 to the Camp 2 hospital was begun, an improvised emergency hospital 
was organized in the former S.S. pharmacy inside Camp 1 within several days of the liberation to provide support for critically ill individuals until they could be evacuated (3). This Camp 1 hospital was organized by Captain Leslie Hardman (the Jewish Chaplain of 8 Corps), Stephen Green (British Red Cross), and two Polish prisoners, Dr. Natolski and Lieutenant Marian Tatarczuk (3). These workers assembled and distributed medication and special food, transported patients to and from the hospital block, and diagnosed and treated critically ill inmates. From mid April to mid May, 200 men and women were treated in the 12 bed inpatient unit of this hospital, and another 200 as outpatients (3). Furthermore, the British medical students organized another acute care hospital in some of the blocks inside Camp 1 for emergency treatment of inmates waiting to be evacuated $(3,16)$.

Even after the evacuation to the Camp 2 hospital, treatment of the starving inmates was a difficult task in primitive conditions $(20,31,32)$ :

"Hospital facilities (in Camp 2) were primitive. The authorities had taken over for use as a hospital a large well-built but incredibly dirty German barracks. All the furniture had been removed and the rooms were at best furnished with plank beds, straw palliasses and blankets. There were two cold water taps on each floor to serve about 75 patients. The water supply often gave out and then the hospital depended on a cart that might or might not come. Hot water we boiled up ourselves on a rather dilapidated primus stove. For a week there was no artificial light except candles in the investigation ward... Fourteen thousand severely ill people had to be treated under these conditions..." (20)

\section{Diseases}

It was not possible to keep systematic records, but attempts were made to describe and estimate the prevalence of the various diseases (8). When the British Army first entered Belsen, the prisoners were dying from starvation, typhus, tuberculosis, dysentery, and murder by the Germans (7, 16). During the first month after liberation, more than one quarter of the 60,000 surviving inmates died because of disease and starvation (3).

\section{Typhus}

Typhus was a difficult problem in the Belsen hospitals. The typhus epidemic in Belsen began in January (15) or February 1945 (33). At least two known incidents contributed to the epidemic. First, a large transport of prisoners was admitted to Belsen in October 1944 without being disinfected because of damage to the showerbath machinery; some of these prisoners carried lice, which then spread throughous the camp (15). Second, a group of Hungarian prisoners had been incarcerate in cattle trucks for ten days prior to arrival Belsen and many had developed typhu雷 failure to segregate these prisoners fron others in Belsen, along with the crowding poor nutrition and lack of sanitation; contributed to the outbreak of the typhu颜 epidemic (14).

An estimated 10,000-20,000 cases of typhus were uncovered when Belsen was liberated on April 15 (22). After the liberation, $25 \%$ of patients admitted to thछ Belsen hospitals suffered from typhus anळ many others admitted during the incubation period developed it later (8). Weil-Feliø్ testing supported the clinical impression that

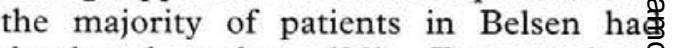
developed typhus (33). Even a largê percentage of patients (9 [47\%] of a sample of 19 patients) who denied having ha\& typhus tested positive with the Weil-Felis reaction, demonstrating that they had had the infection (33) (Table 2).

Table 2. Typhus in Belsen Camp. *

$\begin{array}{lr}\mathrm{N}^{\star \star} & \text { Weil-Felix } \\ & \text { positive }+\stackrel{0}{\circ} \\ & \text { no. }(\%) \\ & \end{array}$

May 1945

June and early July 1945

Total

Patients who denied typhus

Patients who reported typhus

26

$12(46 \%)$

$9(41 \%)$

$21(44 \%) \supseteq$

* Data of Majors Griffin, Morris and Prior, reported b Mollison (33).

** Sample size from which percentage estimate was made. + Positive result defined as titre of 150 or more.

The clinical symptoms and signs of typhus included high fever, violent headache delirium, tinnitus, deafness, palpable spleerE and rash (13). Parotitis occurred in typhusipatients, particularly those who wer dehydrated, and sometimes requireop drainage (13). The mortality rate from typhus was estimated at $10-20 \%$ at age $20 \mathrm{yr}$ 웅 and almost $100 \%$ at age $50 \mathrm{yr}$ (13).

The typhus epidemic in Belsen continued. to spread after the liberation (9), but thes situation improved after the camp was cleaned and disinfected. The British werew assisted by Capt WA Davis, a representativeo of the United States Typhus Controdo Commission $(7,8)$, who estimated that $95 \%$ of the lice were eliminated by the first delousing of the huts (14). The epidemic was eventually controlled by the delousing, evacuation and burning down of Camp $1, \frac{\Omega}{\mathrm{D}}$ but not until many inmates had died. Those who suffered from typhus also had complications, including thrombosis 0 thrombophlebitis, gangrene, bronchopneumonia, meningitis and severe attacks of chest pain $(7,28)$. Several (10 according to 
(8), 20 according to Lieutenant Colonel MW Gonin (21), and 30-40 according to (13)) British RAMC workers also contracted typhus (7) while cleansing and delousing the prisoners, and between four $(34,35)$ and six (13) of the medical students returned to England sick with typhus despite previous inoculation.

\section{Tuberculosis}

Early clinical estimates suggested that pulmonary tuberculosis was advanced in $6 \%$ of hospital admissions (8). However, a subsequent radiographic study revealed that over $20 \%$ of hospital patients had pulmonary tuberculosis (8), and in another series of 1575 suspected cases, over $30 \%$ of patients had extensive and often bilateral involvement (28). However, among the sickest patients, the prevalence of tuberculosis was greater. It was estimated clinically that one third of the prisoners in Camp 1 had tuberculosis (14), and other studies in the Camp 2 hospital which included radiographic and autopsy data revealed that over $40 \%$ of the sickest patients had evidence of pulmonary tuberculosis (33).

A clinical triad of typhus and starvation resulting in reactivation of pulmonary tuberculosis was estimated to have been present in over 1000 patients in Belsen (36). A high proportion of patients who died of starvation had active tuberculosis noted at autopsy (8), and extensive tuberculous infection was noted in $67 \%$ of those in which the cause of death was known (33). After the typhus epidemic came under control, tuberculosis became the greatest cause of death in Belsen (28). It was concluded that any starving patient who did not improve after a proper diet had been administered (33), or who had persistent anemia (28), was likely to have tuberculosis (Table 3 ).

Complications of tuberculosis included pleural effusions in half of the involved patients, acute pericarditis, diffuse miliary tuberculosis, tuberculous laryngitis, and tuberculous meningitis (28).

Table 3. Prevalence of tuberculosis (TB) in Belsen Camp.

\begin{tabular}{|c|c|c|c|}
\hline Population & $N^{\star}$ & $\begin{array}{c}\text { Patients with TB } \\
\text { no. }(\%)\end{array}$ & Reference \\
\hline Prisoners in Camp 1 ** & - & $(>33 \%)$ & (14) \\
\hline Patients in Camp $2 \dagger$ & 331 & $(>20 \%)$ & (8) \\
\hline Patients in Camp $2+\dagger$ & 1575 & $(>30 \%)$ & (28) \\
\hline Starvation cases in Camp 2\# & 64 & $27(42 \%)$ & (33) \\
\hline Deceased with known cause of death\#\# & 18 & $12(67 \%)$ & (33) \\
\hline
\end{tabular}

* Sample size from which percentage estimate was made.

** Clinical estimate of inmates prior to evacuation to Camp 2 hospital.

† Radiographic screening of miscellaneous patients in Camp 2 hospital selected at random; radiography deferred in those patients too ill to be screened radiographically.

H These workers estimated that $25 \%$ of all patients in Belsen had acute tuberculosis. \# Data from radiography, blood testing, and autopsy.

\#\# Method not explicitly noted in (33), but the context suggests that these were autopsy data; autopsy studies cited elsewhere noted "active tuberculous disease in the lungs of a very high proportion of cases of starvation" (8).
Diarrhoea

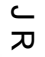

Almost all inmates of Belsen suffered fromp diarrhoea - $80 \%$ according to one estimate (37). The etiology of the severe, uncontrolled diarrhoea of Belsen was nutritional o infective (38).

The great majority of cases of diarrhoeæ was of nutritional or dietetic etiology, and? improved with a controlled diet (8). Severa $\overrightarrow{\vec{e}^{2}}$ drugs were used, including opium, Albucid? sulphapyridine, sulphathiazole, (Tannalbine "a German drug of unknown composition"(5)) nicotinic acid, chalk, charcoal, and kaolin $(5 \%$ $10,14)$. In a group of patients with pellagra-like vitamin deficiency, diarrhoea improved with nicotinic acid (28):Nonetheless, the nutritional diarrhoea was $\vec{\omega}$ generally difficult to control and the: associated dehydration contributed to death (14).

Although dysentery was not diagnosed in $\vec{A}$ Camp 1 during the first few days aftero liberation (7), it was felt to be present and was treated in the Camp 1 hospital witho eleodron injections as well as a diet of biscuits and hot cocoa or milk (3). Bacillaryo dysentery was subsequently documented in? $8-15 \%$ of patients with diarrhoea, primarily resulting from B. dysenteriae Flexner II (8). These patients responded to 8 sulphaguanidine or sulphathiazole except when severe starvation was present (8).. Another study of rectal swabs revealed pathogenic organisms in $17 \%$ of 100 cases of diarrhoea, with Sonne bacilli demonstrated in $15 \%$ and Flexner bacilli in $2 \%$ (38). Infective diarrhoea was also caused by을 intestinal tuberculosis (28).

\section{Starvation}

Starvation was widespread in Belsen from at least January 1945 until the liberation $(8 \stackrel{0}{\stackrel{\Xi}{2}}$ 33). Malnutrition from "plain lack of food and $\bar{\sigma}$ water" was evident in all patients, and $60 \%$ of $\frac{0}{\stackrel{0}{F}}$ inmates had starvation disease (8). The starvation cases were characterized by extreme emaciation, dehydration and apathy,, and hunger edema was present in $6 \%(8)$. The severe emaciation of the corpses showedo that starvation was universal among them $>$ prior to death (8). Not only was starvation a? primary cause of death among inmates in $N_{\infty}$ Belsen, but it also facilitated the spread of $N$ lethal infections.

The chronic food deprivation in the $\frac{\omega}{\sigma}$ concentration camp became progressively worse during the four months before the $\bar{\Phi}$ liberation of Belsen. A Hungarian woman $\stackrel{?}{+}$ doctor reported that in January 1945 the $\bar{T}$ prisoners received $300 \mathrm{gm}$. (one sixth of a $\frac{\mathrm{O}}{\mathrm{D}}$ loaf) of bread daily along with varying $\frac{\mathrm{P}}{\mathrm{Q}}$ amounts of a thin, watery "soup" of mangel- $\frac{0}{2}$ wurzel, a common beet used mainly as cattle feed $(8,33)$. Subsequently, there was a periodo when the "soup" was given only three nights a week and a small amount of margarine or $\frac{\overline{0}}{\overline{2}}$ jam on the other four nights (33). In March 
only one-twelfth of a loaf of bread was given for supper, and when there was no bread, mangel-wurzels were eaten (33). In April there was no bread distributed; the prisoners received a half litre of the thin "soup" daily and nothing else (33). It was considered remarkable that some inmates had survived despite a diet of 400 calories or less for two to three months (38). The distribution of food had been arbitrary, and those who did not have the strength to stand in line had often missed the daily ration (8).

The British relief workers documented the extreme physical deterioration of the starving inmates, especially the "Muselmänner" inmates who were on the verge of death because of extreme starvation and exhaustion $(33,39)$. As noted by one of the medical student volunteers:

"Physically, the most startling sight was the degree of emaciation to which (the inmates) had been reduced. 'Skin and bone' here was a literal description. Their heads were no more than parchment covered skulls, their thighs could be circled by finger and thumb and it was easy to grip the bodies of their vertebrae through their anterior abdominal walls. Their muscles were mere fibrous strands and the women's breasts just wrinkled flaps of skin... many were too weak to move..." (5)

The sick lay on their bunks, apathetic, indifferent to the deaths occurring around them, many leaving their food untouched, and incontinent of faeces (33). The faces were "appallingly thin", "the eyes were sunken and the cheek-bones jutted out," and the heads shaven (33). They were so thin that "the ribs stuck out, and it was difficult to use a diaphragm type of stethoscope because it simply bridged across two ribs and made no contact with the skin dipping down in between" (33). "In some cases their superficial bones had burst through the skin" (28). The feet and ankles were swollen, with the "leg as thin as a stick with a fat swollen foot on the end of it" (33). The "muselmänner" had large bed-sores on the buttocks and the lower back, and would cry out, "Scheiszerei," because of the severe diarrhoea (33).

In a group of 11 starving patients who were strong enough to stand upright on scales, the original body weight of 47-80 kg had decreased to $25-45 \mathrm{~kg}$; the range of percent loss of original weight in this group was 29$56 \%$ (33). The weight loss was more extreme in the thinnest patients, who were too ill to be weighed, and they died earlier (33).

Hematologic studies in 75 starvation cases showed that almost all were anaemic, with average hematocrit in men $31 \%$, women $29 \%$, and children $30 \%$ (33). The anaemia was normochromic and normocytic, and bone marrow examination in several cases revealed normoblastic erythropoiesis, suggesting that the anaemia was a result of decreased production of red cells $(28,33)$. The sedimentation rate was elevated in patients with starvation, even when infection was not evident (33).

Circulating blood volume was decreased $\square$ by $16-21 \%$; average blood volume was 4.33 litres in a sample of 6 males and 3.17 litres inz 10 females tested (33) (normal 5.1 litres in males and 4.0 litres in females (40)). Another report estimated the circulatory capacity too have been one third to one half normal (41). Autopsy studies showed that heart weight $\overrightarrow{\vec{F}}$ was an average of $40 \%$ less than normato (average heart weight, $186 \mathrm{gm}(\mathrm{N}=17) ;$ 을 normal, $310 \mathrm{gm})(38,41)$; "the adult heart $\frac{\overline{\bar{s}}}{\stackrel{\text {. }}{-}}$ had atrophied to about the size of the heart of $a \mathbb{Q}$ ten-year-old child, and the aorta was about thes size of a pencil" (28).

Other autopsy findings included almost complete absence ( $95 \%$ decrease) of normale body fat (38). Fatty change was noted on the liver. The large bowel was distended, thin, and transparent, with many ulcers, scars, bleeding points, and absent haustration. The rectum often contained undigested foodo (38).

The relief workers had to determine the appropriate type of food for the chronically? starving prisoners (19). The camp inmates $\vec{O}$ had been adapted to subsistence on little food and water, and the gastrointestinalo system was unable to digest a larger meal, especially one containing fatty food (8). In the first two days after liberation, when the British soldiers gave the starved inmates fullo army rations, the inmates developed abdominal pain, vomiting and diarrhoea, and an estimated 2000 died as a result, "many dropping dead literally at the first mouthful" (8, $27,38)$. Subsequently, the inmates were fedo gruel, soup, tea and a glucose-vitamin mixture with hot water $(5,16)$.

Food in Camp 1 was prepared in five cookhouses and delivered by Army truck to the individual barracks (5). In the early days and weeks breakfast consisted of tea or milke्ळ and biscuits, and lunch included vegetable $\underset{F}{\mathscr{E}}$ soup, potatoes and occasionally meat stew (5). Tea and biscuits were again distributed in 3 the afternoon (5). This diet provided lessi than 1000 calories per day, dictated by the acute shortage of supplies (5). Repeatedo breakdowns in the water supply further complicated the feeding problem (5). The food supply gradually improved, but noț until the third week of May was any butter or margarine available (5).

The importance of careful control of volume intake, because of the diminished circulatory capacity, was also recognized $(8 \stackrel{0}{\circ}$ 41). Therefore, a three-stage diet, high in? protein, was devised which enabled gradualo increase of daily caloric intake for the starving inmates. The first stage of $800 \stackrel{\Omega}{\Omega}$ calories per day for 3-4 days was based $\varrho$ primarily on skimmed, fresh, or powder reconstituted milk with added sugar, salt, 8 water and vitamins. This was followed by second stage of 1700 calories for severa days, and a third stage of 3000 calories (8)? 
Bengal Famine Mixture was tried, but was unsuccessful in Belsen because it was too sweet for the inmates, "loathed by all and sundry" $(5,21)$, and caused diarrhoea ( 3,9 , $10,38)$. Other diets used, presumably for the healthier patients, included some potatoes, soup, a little meat and white bread if available (38). However, food shortages persisted beyond mid May, and even the relief workers found food supplies for themselves limited (16).

Strict supervision of the supply and distribution of food by British personnel was necessary to make certain that the very sick actually received the food, because stronger internees or German personnel would steal the food for themselves or their friends outside the hospital (8). Inmates with nutritional diarrhoea often refused to eat, and feedings had to be carefully supervised (38). The majority of the starving inmates were able to take food and water by mouth, and only less than $5 \%$ required intravenous therapy or an esophageal feeding tube (8). The use of an esophageal tube was limited both by the inmates' fear of torture $(9,10$, 32 ) and the dried atrophic nasal mucosa which caused difficulty in passing a tube (32). In the Camp 1 hospital, patients with desperate weakness resulting from starvation were given injections of leptazol (Cardiazol) or coramin for their hearts and glucose for energy $(3,16)$.

Fourteen days after the liberation of Belsen, a small team from the Medical Research Council arrived to study the relative efficacy of skimmed milk, protein hydrolysate, and serum in the treatment of starvation $(20,31,32)$. The protein hydrolysate, an acid hydrolysate of casein, was so nauseatingly unpalatable and also appeared to irritate the gastrointestinal tract that patients did not take it for more than a day $(8,16,20,28,38)$. Some patients had vomiting, severe colic and watery diarrhoea in one case, a half a bucket - after taking oral hydrolysate (32). Intravenous administration of protein hydrolysate was complicated by severe rigors and venous thrombosis (5). Thus, protein hydrolysate became suspected by the suffering inmates of being a "new form of torture," further contributing to the failure of this therapy $(5,42)$. Therefore, it was concluded by Dr. Janet Vaughan of the Medical Research Council group that overall efficacy of protein hydrolysate was poor and that use of protein hydrolysate was not practical under field conditions $(20,31,32)$. As a result, 270 litres of the hydrolysate was destroyed - a paradox of waste in a situation of great need (27). Other disadvantages of the protein hydrolysate included the potential for tryptophan deficiency and volume overload $(28,43)$. Nonetheless, it was suggested that oral protein hydrolysate could be useful together with other foods because it appeared to stimulate the appetite of the starving inmates who were especialto weak and anorectic (38). However, the mo satisfactory method of feeding those wh could swallow was the use of dilutecs unsweetened condensed milk or skim mil powder in water (28).

Hunger (oedema) edema was generalo managed with feeding, as well as transfusion. of double strength plasma or blood (28). I⿳亠丷⿵冂丶 some patients with persistent (oedem edema despite improved nutrition, a trial Salyrgan (mersalyl - a diuretic) resulted $i \frac{5}{10}$ reduction of edema and stimulation $\cong$ appetite, with clinical improvement (28).

\section{Paediatric conditions}

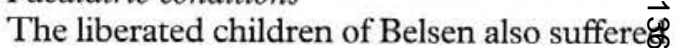
from starvation, marasmus, typhu tuberculosis and fear syndromes $(7,36)$. very high percentage of children in Belseh were infected with tuberculosis, with $80 \%$ of children (average age, $7.1 \mathrm{yr}$ ) testing Pirquet\& positive (36). In Belsen it was "quit ordinary" that deliveries were done in wome日 suffering from typhus and in mid May manȳ babies were still dying of neonatal sepsis (7)0

The complexity of the medical and sociois problems of these children was exemplifie $\Phi$ by the following case report:

" $A$ boy, Z.Z., aged 5, was admitted to the 8 children's hospital, Belsen, from the general hospital on the death of his mother. His mother, an Austrian Catholic, died at Belsen of typhus. The father, a Slovak few, last heard of in Sachsenhausen, was probably dead. A sister, aged 6, was alive and well in the camp. Two other children died in Ravensbrück lager. Nothing was known of the patient's past (medical) history.

On admission he was very emaciated. He lay rolled up in a ball under the bedclothes, moaning, and wouldn't eat or speak. Examination revealed pleurisy with an effusion on the right side and some infiltration in the right and the upper zone of the left lung. The temperature was irregular, rising to $101^{\circ}$. Sedimentation rate, $101 \mathrm{~mm}$. first hour (Westergren). Pirquet plus. 10 c.cm. of serous fluid was aspirated to exclude empyema.

The child was hand-fed with specially appetizing meals while being talked to in his $\tilde{N}$ own language. He was given a high-protein diet with an addition of vitamins and calcium and at first was kept in a warm room; later he was placed in the open air. After one week he began to talk; after two weeks his appetite returned; and after eight weeks the sedimentation rate was $50 \mathrm{~mm}$. He was then evacuated to Sweden. The latest report states that he has put on $7 \mathrm{lb}$. (3.2 kg.) and is now almost well.

Comment...the final problem of the Belsen children...is a social one of the most profound complexity... What is to become of him? Is he to be brought up few or Catholic? Is he to be left in an orphanage? He has 
found a temporary refuge in Sweden, but what of the future?" (36)

\section{Psychological status}

The medical officers observed that "many (of the inmates) are as wasted in mind as they are in body" (7). Nonetheless, it was concluded that psychosis and psychoneurosis, excluding that secondary to typhus (16) and other toxic infections, was less evident among the surviving inmates than in other communities, "possibly because only the more extrovert and robust psychological types had survived the ordeal of their captivity" (8). Patients with frank psychosis from schizophrenia or post-typhus mental derangement were treated in an asylum organized in Block 27 of the Camp 2 hospital (3).

The most notable psychological abnormality was anti-social behaviour and selfishness, proportional to the degree of malnutrition (8). It was evident to the British that the "mortal starvation conditioned all happenings in the camp" (3). With more advanced starvation, consideration for others became progressively limited to friends, immediate family and, finally, personal survival $(5,8)$. There was a "blunting of sensitivity to scenes of cruelty and death," even among children who had grown up in concentration camps (8). Generalised apathy was observed, with inmates noted walking about the camp without clothing and eating meals from the same bowls used as bedpans (5). However, normal behaviour rapidly returned with improved bodily health, "leaving only a feeling akin to that of having experienced a bad dream" (8). The sick children were noted to have "terror symptoms" and apathy, but both improved with physical recovery (36).

The sick inmates of Belsen were dreadfully fearful of the British relief workers, undoubtedly because of their horrifying experiences with the German physicians during the war (6). The inmates recalled how the German doctors had given intravenous benzol, benzene, petrol, or creosote to paralyze their victims prior to sending them to the crematorium $(6,7,10,20)$. Therefore, when the British workers attempted to start an intravenous drip or use a syringe to collect a blood sample, the inmates shrieked, "Nicht krematorium!" (6, 7, 20, 21). They reacted similarly when the British attempted to segregate inmates for treatment or pass a nasal tube (9). This was compounded by difficulty in communication because there was no common language between the British workers and the inmates, who were mostly from eastern Europe $(20,28,32,37)$.

In the healthier inmates, such as those of Camp 3, a behaviour referred to as a form of "famine psychosis" was observed (3). Despite apparently adequate supplies of food, inmates complained of hunger, and "were

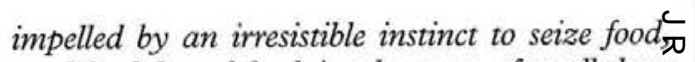
steal food, hoard food, just because, after all thos years of terror, they were still unsure of their fate still unsure that the day when one had divec upon a piece of potato peel, at the risk of a bulle $\underline{\mathbb{Q}}$ in one's belly, might not return" (3).

By the middle of May 1945, the main factors aside from physical illness ano? weakness which prevented the convalescen $\overrightarrow{\vec{\sigma}^{\prime}}$ inmates from having a normal interest in lifê in general included post-typhus menta£ derangement and anxiety about the fate oos

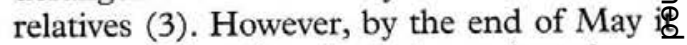
was noted that "apathy had gone from them. Their sense of shame and decency had come back completely. Hope was rekindled within them and they thought of the future once more" (5) $\vec{\omega}$ Nevertheless, the preoccupation with the fat of relatives dominated the lives of the majority of Belsen survivors throughout the summer (3).

Other conditions

Many other illnesses in Belsen wer\& documented by the British medical team? including sepsis, pressure sores (including those of the emaciated, concave "Belse日 buttock"), ischiorectal and other abscesses: rectal prolapse, piles, neglected wounds; gangrene, extensive scabies (6-40\%) erysipelas, typhoid, diphtheria, acut $\overrightarrow{\mathrm{e}}$ nephritis, cancrum oris, parotitis, sore gum: gastric ulcers, malaria and the red, smoot "Belsen tongue" $(5,7,8,10,16)$. Gangrene क्ष the extremities was nutritional, post-typhug or thrombotic, and femoral and iliac veif thromboses were common (5). Amenorrhe was universal (5).

Surgical emergencies included acu传 appendicitis, bowel obstruction and urinary retention (5). Acute cholecystitis was no uncommon (28). Acute upper abdomin क्ष pain, attributed to alimentary atony, war observed in starving inmates after beginnine the feeding program, but improved within few days (28).

Several conditions were observed for which no satisfactory explanation could be determined, such as hepatosplenomegaly io inmates with normal hematologic studies (28). Another curiosity was termed "Belse Fever," a self-limited febrile illness of $2-\overline{3}$ weeks duration associated with splenomegaty and leukopenia, but without ras\$ investigation showed negative Widal test ang no abnormal organisms in blood, urine, \% stool (28).

The British Medical Students In the first week of April 1945 the 21st Armo Group appealed to the British Red Cross supply medical assistance for thousands of starving people in Holland (44). The Ret Cross did not have enough workers for th $\$$ effort, and therefore, 100 volunteers we solicited by the Red Cross (44) and the Ministry of Health (25) from among 
food, those

Table 4. London medical schools which sent student volunteers to Belsen Camp. *

\author{
St. Bartholomew's Hospital \\ Guy's Hospital \\ King's College Hospital \\ London Hospital \\ Middlesex Hospital \\ St. Mary's Hospital \\ St. Thomas' Hospital \\ University College Hospital \\ Westminster Hospital
}

* From $(22,25,35)$. The names of 86 of the 96 students are listed in $(22,35)$. Photographs of the students are published in $(4,14,22,35,72)$.

students in the final 18 months of study in the London medical schools $(13,14,16,44)$. However, the liberation of Holland was delayed and the students awaited orders (16, 44). In the meantime, Belsen was liberated, and the critical need for assistance was recognized. Therefore, instead of Holland, 96 students $(24,26)$ learned at short notice on April 28, $1945(5,16)$ that they were to depart for Belsen $(5,13,14,16,44)$, under the auspices of the British Red Cross and St. John Ambulance (25). The first students arrived at Belsen Camp two days later on April 30, 1945 (26) and they remained until May 28-29, $1945(16,22,45,46)$ (Table 4).

The supervisor of the medical students was Dr. AP Meiklejohn, member of the Rockefeller Foundation Health Commission and the Nutrition Section of the European Regional Office of UNRRA (United Nations Relief and Rehabilitation Administration) $(26,42)$. The students immediately went to work in the Horror Camp, responsible primarily for food distribution for the starving inmates and improvement of living conditions $(3,5,26,44)$. In the days after the liberation the strongest inmates took whatever food they could get and became sick from overfeeding, whereas those too weak to leave the barracks died because they could not feed themselves (26). The students took over the responsibility for the barracks in the Horror Camp - two (24) or three students in each of the barracks, or occasionally, one student for one or more barracks (26). Each of the barracks contained $100-150$ patients in addition to 200-300 inmates who were able to feed themselves (26). Therefore, some of the students had as many as $400-600$ patients under their care (5).

The students had daily conferences with Meiklejohn and with the officers in charge of the kitchens to plan out the work (9). However, the students were required to use their own initiative and "improvisation was the order of the day" (14). There was a great shortage of help, especially after the healthier inmates who had provided some assistance were transferred to Camp $3(3,27)$. The students themselves washed the filthy barracks of Camp 1, disinfected the floors with creosote and DDT powder to kill the lice, organized the healthy inmate volunteem for work in the hospital and fed the weakes of the starving inmates individually $(3,5,1$ 蛋, $24,26,27)$. Within two weeks of arrival the students had washed, disinfected an reclothed 1200 patients (26).

The students also organized an emergenơ hospital in the Horror Camp $(3,10)$, "entire by their initiative... in which the worst cases tha had to wait to the last (to be evacuated to Car 2) were nursed and undoubtedly saved" (4․ㅗ․ 46). This work was started by a team of te? students on their second day in Belsen, whe scrubbed, disinfected and stocked several \&F the evacuated barracks (5). By the end of the first afternoon they had bedded down over 100 patients and within twelve days thes hospital area consisted of twelve barract containing 1100 patients (5). In addition nursing and feeding the sick and starving inmates, the students set up a dispensary an began medical treatment $(9,26)$. Medicin $\$$ dispensed included aspirin, sulphathiazolo' acriflavine, leptazol and penicillin (16) opium, Tannalbin, nicotinic acid, charcoa! and sulphathiazole were used again $\mathbb{D}$ diarrhoea (5). Mittigal, a German drug, wi used to treat scabies (5). Bedsores wero dressed and abscesses were drained $\left(5 \hat{N}^{\circ}\right.$ Medical and nursing supplies were extremel$\Phi$ lacking, with only three bedpans for one hut in which there were over 80 patients with diarrhoea (10). Drugs were limited in supp especially during the first two weeks of Mag and the language barrier made evaluatio and explanation of treatment difficult ( 14). Nonetheless, by giving out a pill, eveģ one of limited therapeutic value, the students noticed improved morale and reduce apathy in the inmates $(9,14,26)$. On Ma 14 , two field transfusion units were obtaine which were used to administer bloo plasma, concentrated serum, glucose an protein hydrolysate $(5,16,28)$; howeve intravenous therapy was complicated by poow venous access because of collapsed veinș venous thrombosis, severe rigors and volum 8 overload resulting in pulmonary (oedema edema, heart failure, ascites and death (5). 9

The immersion of the medical students if the realities of the Horror Camp also resulte in some of the clearest descriptions of the situation of individual inmates as well as the overall state of the camp $(9,10,13,14,27$ 鹿 $29,30,38)$ :

"We took a look round. There was faeces all $\sum_{0}^{\circ}$ over the floor, the majority of people having $\bar{\Phi}$ diarrhoea and passing a stool like a small $\stackrel{?}{+}$ cow pat - there were tin cans and lumps of $\frac{T}{0}$ black bread all mixed up with it, and the $\underset{\mathbb{D}}{\vec{D}}$ place could not have been swept for years. $I \stackrel{\mathbb{D}}{\mathbb{D}}$ was standing rather aghast in the middle of $\frac{\mathrm{Q}}{\sigma}$ all this filth, trying to get used to the smell, which was a mixture of post-mortem room, $a$ $\frac{8}{0}$ sewver, sweat, and foul pus, for none of the windows were open, when $I$ heard $a \stackrel{\overline{0}}{=}$ scrabbling on the floor. I looked down in the 
half light and saw a woman crouching at my feet. She had black matted hair, well populated (with lice) and her ribs stood out as though there were nothing between them, her arms were so thin that they were horrible. She was defaecating, but she was so weak that she could not lift her buttocks from the floor and, as she had diarrhoea, the yellow liquid stools bubbled up over her thighs. Her feet were white and podgy from famine oedema and she had scabies. As she crouched, she scratched her genital parts, which were scabetic too... (The bunks) were all smeared with faeces, because the people with diarrhoea did not bother to get out of bed. The result was that urine and faeces dribbled through the wooden boards of the top two bunks on to the lowest one and as this last was the least comfortable, all the dying and weaker patients could be found there..." (10)

After the evacuation of Camp 1 was completed, the students worked in the hospitals of Camp 2 and 3, where there remained 12,000 sick $(9,10,26)$. By now, there were more drugs, a minor operating theatre and radiography equipment (9). The students were now able to examine patients properly, make diagnoses and provide more appropriate drugs and treatment $(9,14)$.

The medical students also assisted in the social relief work for the inmates. One survivor, a German Jewish nurse who had learned English prior to the war, described how the students picked her up at her barracks daily so that she could serve as a translator in the collection of demographic information from the inmates; thus, lists of survivors were made to facilitate contact with relatives who had survived the war (47).

Regarding Meiklejohn, one student commented that "his calm, diplomatic handling of students and the higher authorities greatly added to the effectiveness of our efforts" (13). Meiklejohn noted that the students brought "initiative, energy, enthusiasm, team spirit, medical knowledge, and hope" (24), and he concluded that "there can be no doubt that the large majority of the patients in this students' hospital (of Camp 1) owed their lives to this achievement" (26). Glyn Hughes added that the students "were given the heaviest of responsibilities and their initial efforts depended entirely on their own initiative. One and all they threw themselves into the task with unbounded enthusiasm; they worked long hours in the worst possible conditions and never spared themselves" $(45,46)$.

\section{Other Workers}

Although most of the rescue operation in Belsen was performed and directed by the British, there were others who made important contributions. By June 9, UNRRA had sent 205 teams, each with doctor and nurse, to help the Displaced Persons (D.P.) in Germany and had plans to send a total of
450 teams (42). The physicians were ${ }_{p}^{c}$ recruited from France, Belgium, Poland and Czechoslovakia (42). Sweden offered to accept 10,000 D.P., sick people and children $(36,42)$ and 7000 patients were sent there from Belsen to convalesce (3). Americano volunteers helped in the evacuation of the Horror Camp $(10,21,48)$, as well as doctors? and nurses from Switzerland (7). A large group (100-150) of Belgian medical students: $(3,5,16,22)$, including a group ot흠 approximately 12 medical students from Louvain (49) and members of the Shae $\mathbb{\complement}$ Medical (Belgian) Mission (M. Johre्w Moerman, Ghent Medical School) (36), alsocame to Belsen to assist in the rescue operation.

The surviving inmates also offeres assistance. When the British Army entere of Belsen on April 15, they found that everf? before the liberation, attempts had beenf made in the women's camp to maintain somes order and cleanliness, despite the thousandsi of dead, weak and sick women throughoug the camp (1). "...the care that had been taken? of the children was most noticeable... and medica $\bar{b}$ help went on whatever happened. One woman gynaecologist was conducting all the obstetrio cases, 5 to 7 a day, and for several days had had to work without water" (1) . After the arrivaB of the British:

"...many hundred capable and well qualified people among the victims of Belsen... voluntarily and without payment helped the British in their formidable task... (They) formed an indispensable auxiliary staff (which) consisted of doctors, nurses, interpreters, cooks and, later, schoolteachers, librarians, entertainers and political helpers for the War Crimes Commission. Without the help of these hundreds of able, and often selfless, volunteers it would have been impossible to run either the hospital or the rest-camp" (3).

The Senior Medical Officer of the British Red Cross Commission for Civilian Relief in Belsen Camp, WRF Collis (36), commented "Nor must the gallant efforts of the interne doctors and nurses be forgotten. Many were sick and weak themselves, but, forgetting their tireds and wasted bodies, they have worked and fough beside our medical personnel to their utmos N power" (7).

\section{Rehabilitation}

After the first two months following the liberation of Belsen, when the immediate danger to the lives of the remaining survivors had passed, the goals of the relief workers shifted from saving lives to rehabilitating individuals. As the last barracks of the Horro? Camp were evacuated and burned down activities were organized to entertain and raise the spirits of the survivors. In Camp 38 a library and recreation room was organize in mid May, within one week, by Derrick Sington of the British Army and Mrs: 
were $\mathrm{d}$ and ed to ildren there rican f the ctors large dents $p$ of from Shaef John also scue ered ered even een ome inds lout ken lical nan tric had ival
Montgomery and Miss Heard of the British Red Cross, complete with arm chairs, gramophones, pianos and two hundred volumes (3). English language classes were offered and within three days, 400 inmates registered (3). In July, linguaphone classes in English were started in Camp 4, supervised by Girl Guide Teams (3).

On May 21 the first of a series of open air dances took place (3). Three nights later, on May 24, an "International Cabaret" was given in Camp 3, with dances and songs performed by survivors (3). This was so successful that a more elaborate program was arranged beginning June 4 for four nights to a full house of 800 spectators in the tented theatre of the Panzer Training School (Camp 2) (3). During June and July, the cabaret shows became a weekly event, and the open air dances were repeated every other week (3). In mid June, under the direction of Camp 4 director Major Berney and Lady Abrahams of the British Red Cross, a community centre was organized in a block in Camp 4, complete with music room, card room, billiard room, library, news room, studio, barber and workshops (3).

Activities for the 300 child survivors remaining in Belsen in April, many of whom were sick, tubercular and without family, were also organized, including an elementary school initiated by Lieutenant Hodges, the Welfare Officer (3). Most of the teachers in this school were young women who had been inmates of Belsen (3).

In August 1945 UNRRA took over responsibility for the Glyn Hughes Hospital in Belsen, with 29 relief workers from 12 countries, in addition to DP workers (50). The work spirit was strong, despite the language difficulties (50). The Chief Welfare Officer of UNRRA in Belsen, Dr. Erika Fischova-Gachova from Czechoslovakia, taught and encouraged the patients of the Glyn Hughes Hospital to make all types of handiwork, including toys, bags, baskets, clothes, gloves and belts, and thus, the sick were encouraged to move stiff joints and paretic limbs (51). Self-respect and confidence came back slowly (51). An exhibition of their creations, including cartoons by a hospital patient, was held in the UNRRA offices in London from October 31 to November 7, 1945 (51). Individual relief workers took initiative in helping survivors learn new skills; for example, a Dutch physician taught my mother, recently recovered from typhus and starvation, how to drive a car (52). A post office was organized for the DP in Belsen by Mr. Whitehead of the British Red Cross to facilitate the search for surviving family members (49). Whitehead also obtained lists of survivors in twenty other camps which were published, circulated in Belsen and sent to other camps to facilitate the search for relatives (3).

As the survivors regained their health, they organized themselves in the spirit of self-hetp and community. The first issue of Unz:r Sztyme, the first Yiddish newspaper in 㕻 British Zone of Germany, was published Ju 12, 1945 by the Jewish Committee in Celk, a town near Belsen $(53,54)$. A Centfil Jewish Committee was organized in Belsegू, which held the first Jewish Survivors; Congress on September 25-27, 1945 (5풀, 56). Community activity included maintenance of the Glyn Hughes Hospit coordination of assistance from UNRRA an the Joint Distribution Committee (57), aipd organization of schools for the children [5\&], a children's home (59), religious institutio $\overrightarrow{\mathrm{s} S}$ $(60,61,62)$, sports clubs $(63,64)$, a Yiddisth theatre group (65), and political activity $\left(5 \frac{5}{5}\right.$, $56,66)$.

The senior British medical office understood the problem of statelessness of the liberated eastern European Jews. The personal documents of all the prisoners ha्s been destroyed by the Germans befog Belsen was liberated $(3,5,15)$. In May 1940, Collis noted that "...many thousands of those (internees) from the East, particularly the Polos have no homes to go to, have apparently future, no hope. The problem of what to do wion these forsaken, almost lost, souls is immense, bnot one which if not tackled and solved will make \$l our efforts here mere waste of time..." (7)

However, not all relief workers or milita甲y officials were as sympathetic. In one instanc the Jewish Chaplain of the British Army on Belsen was accused by a high-ranking officơr of being "a Zionist agent" who was "spreadiut Zionist propaganda and trying to wreck Britis plans" (19). One of the medical students wrote that "the Poles, who comprised the largest single national assembly in the place, will not back to Poland and all want to come to Englan or the U.S.A., which to them are lands flowiong with milk and honey..."(9). This student faile to understand that the historic "land flowi with milk and honey" was British-occupie Palestine and that the failure to distinguiș between "Poles" (i.e. Polish Catholics) aro "Polish fews" in the British vernacular ar स木 political posture was a deterrent to tho rehabilitation of these survivors as citizens their own, Jewish State (67).

Despite what was witnessed in Belsen, thas same student had sympathies for tho Germans, writing: "I could not bring myself believe that my nurses were responsible for th war," and "one could not help feeling sorry for the wretched German civilians in all t㱏 completely dead and devastated German cities who had nothing to do but queue for food and servile...” (9). However, these feelings we not shared by others, evidenced by anoth student who commented: "The result of $\frac{0}{8}$ month at Belsen is that I have quite unprintabte views on the whole German race" (10).

Ironically, political differences late resulted in major conflict between the Britis authorities and the liberated Jews of Belsen. 
In May 1946 the British authorities locked the gates of the DP camp at Belsen and did not allow the Jews to exit the camp (68). The Belsen Jews became active in the political protest against the British policy opposing Jewish immigration and statehood in Palestine $(67,69)$. Despite these conflicts with the British authorities, the surviving inmates recognized the extraordinary efforts made by the military and non-military medical relief workers long after they regained strength and departed from Belsen:

"At this point should, with praise and thanks, be mentioned the detachments of the British army, which were the first to come to us, and especially the Medical Corps, the British Red Cross along with the military doctors and nurses, the young Belgian doctors and the hundreds of medical workers, who from a long list of countries volunteered, and with superhuman strength and unnatural perseverance brought help to those for whom merely a good word and a simple drop of water was even more important than bread in those horrible moments. Their names and images will until the end of time remain engraved in the hearts and memory of the thousands of survivors." (70)

Indeed, the expeditiously organized medical rescue operation in Belsen was one of the most important humanitarian events of the first few days and weeks after the liberation, thanks to which thousands of inmates were saved from a rapid and certain death. The operation will remain a landmark model for disaster relief (71).

\section{Acknowledgements}

Presented in part at the Ninth Annual Paul Trepman Memorial Lecture, Jewish Public Library and Montreal Holocaust Memorial Centre, Montreal, Canada, May 12, 1997. Translated by the author from the Yiddish article published in the Forverts (Yiddish Forward), 100th Anniversary Issue, Vol CI, No. 31132, Section three, pgs. 6 and 20-23, May 16, 1997. The author is grateful to Len Levin, M.S.L.I.S., for library assistance, and to Susan Date, Hilde Goldberg, Grete Munn, David Rosenthal, Mordechai Striglerzl", and Babey Trepman for helpful discussion.

\section{References}

1. Belsen concentration camp: the medical services take over. Lancet 1945;1:604-605.

2. Gwyn Evans R. An outline of the role of the medical services in the Second (British) Army's campaign in north-west Europe (1944-45). Part III. $\mathscr{f} R A M C$ 1947;88:129-140.

3. Sington D. Belsen Uncovered. London: Duckworth, 1946.

4. Kemp P. The Relief of Belsen, April 1945: Eyewitness Accounts. London: Imperial War Museum, 1991.

5. Raperport G. Expedition to Belsen. Middlesex Hosp f 1945;45:21-24.

6. The Horror Camp. BMf 1945;1:813.

7. Collis WRF. Belsen Camp: a preliminary report. BMF 1945;1:814-816.
8. Lipscomb FM. Medical aspects of Belsen concentration camp. Lancet 1945;2:313-315.

9. Dixey JRB. Belsen. St. Bartholomew's Hosp $\underset{3}{3}$ $1945 ; 49(6): 76-81$.

10. MacAuslan A. Belsen: May, 1945. St. Thomas's Hosp $\bar{\Omega}$ Gaz 1945;43:103-107.

11. Fiddes FS. Surgery at a casualty clearing station $\Omega$ FRAMC 1945;85:276-280.

12. Collis WRF. Belsen Camp (letter). BM扈 1945;2:303.

13. Hankinson J. Belsen. St. Mary's Hosp Gaș 1945;51:74-78.

14. Gibson TC. Belsen, 1945. London Hosp Ga宅 1945;48:144-148.

15. Küstermeier R. How we lived in Belsen. In: Sington $\mathrm{D}$ (ed). Belsen Uncovered. London: Duckworth

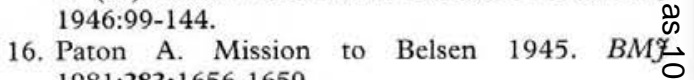
1981;283:1656-1659.

17. Waldron FR. Belsen Camp (letter). $B M \vec{\gamma}$ 1945;1:927.

18. Gwyn Evans R. An outline of the role of the medicat services in the Second (British) Army's campaign in north-west Europe (1944-45). Part IV. FRAMC 1947;88: 165-185.

19. Hardman LH, Goodman C. The Survivors: The story of the Belsen remnant. London: Vallentine $\underset{\mathcal{W}}{ }$ Mitchell, 1958.

20. Vaughan J, Dent C, Rivers RP. The value of hydrolysates in the treatment of severe starvation. Proc R Soc Med 1945;38:395-397.

21. Prescott DT. Reflections of forty years ago - Belsen

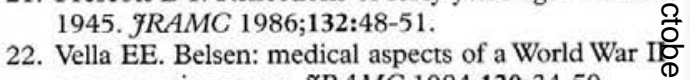
concentration camp. $\mathscr{F} A M C$ 1984;130:34-59

23. Thompson AWS. Malaria control in mobile warfare $\mathrm{N}$ Italian campaign 1943-1945. FRAMC 1946;86:109을 126.

24. Medical students at Belsen. Lancet 1945;1:730.

25. Students as relief workers. Lancet 1945;1:570.

26. The medical students at Belsen. BMf 1945;1:883 884.

27. Walker JB. The feeding problem. London Hosp Ga: $\frac{2}{\mathrm{Q}}$ 1945;48:150-151.

28. Lewis JT, Calwell HG. Medical problems at Belser $\overrightarrow{\vec{\rho}}$ Concentration Camp (1945). Ulster Med $\mathcal{P}_{\vec{\partial}}$ 1985;54:122-126.

29. Morgan JHS. Hut 19. London Hosp Gap

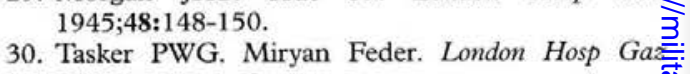
1945;48:151-153.

31. Royal Society of Medicine. Physiology and treatment of starvation: experiences in war-starvec Europe. BMF 1945;1:818-820.

32. Medical Societies: Royal Society of Medicine (Protein hydrolysates: experience at Belsen). Lance 1945;1:723-724.

33. Mollison PL. Observations on cases of starvation af Belsen. BMF 1946;1:4-8.

34. MacAuslan A. Belsen: medical aspects of a WW II을 concentration camp (letter). $\quad$ RAMCD 1984;130:199.

35. Wand LGR. Belsen: medical aspects of a WW II concentration camp (letter). FRAMCS 1984;130:201.

36. Collis WRF, MacClancy PC. Some paediatriơ problems presented at Belsen Camp. BMf 1946;1:273-275.

37. Roberts H, Potter P. Belsen Camp (letter). BM 1945;2:100.

38. Coigley MHF, Stephenson J. Starvation and its treatment with protein hydrolysate: Belsen, 1945.7 St. Thomas's Hosp Gaz 1946;44(1):2-9.

39. Gutman I. Muselmann. In: Gutman I (ed) $\stackrel{\mathbb{D}}{\Omega}$ Encyclopedia of the Holocaust. New York: Simon \& Schuster Macmillan, 1990:1009-1010.

40. Moore FD. Homeostasis: bodily changes in trauma and surgery. In: Sabiston DC (ed). Textbook of Surgery, 12th edition. Philadelphia: W.B. Saunders 1981:23-57.

41. Prior AP. Medical aspects of Belsen (letter). LancelP $1945 ; 2: 512$. 
Belsen

42. The tasks of U.N.R.R.A.: medical services in liberated countries. BMf 1945;1:816-817.

43. Marrack JR. Feeding with digested proteins. London Hosp Gaz 1945;48:142-143.

44. In England now: a running commentary by peripatetic correspondents. Lancet 1945;1:766-767.

45. Glyn Hughes HL. Medical students and Belsen concentration camp (letter). Lancet 1945;1:769.

46. Glyn Hughes HL. Medical students and Belsen concentration camp (letter). BMf 1945;1:857.

47. Munn G. Personal communication. 1997.

48. Gonin MW. Belsen Camp (letter). BMF 1945;2:65.

49. Goldberg HJ. Personal communication. 1997.

50. Layton TB. An international venture (letter). Lancet $1945 ; 2: 613$.

51. A Belsen exhibition. Lancet $1945 ; 2: 618$.

52. Trepman BW. Personal communication. 1997.

53. Olewski R, Trepman P, Rosenthal D (ed). "Unzer Sztyme" (Our Voice), No. 1, pp. 1-12. Yiddisher Komitet in Celle Jewish Committee in Celle), July $12,1945$.

54. Rosenthal D, Farvos a yiddishe zeitung? (Why a Yiddish newspaper?). Unzer Sztyme 1945;1:2-5.

55. Olewski R, Trepman P, Rosenthal D. Baricht funem ershtn she'eres hapleyteh kongres in Daytshland (Report of the first Jewish survivors' congress in Germany). Bergen Belsen: Tsentral Yiddisher Komitet in Bergn-Belzn (Central Jewish Committee in Bergen Belsen), September 25-27, 1945:1-17.

56. Trepman $P$. Der yiddisher heftlings kongres (The Jewish prisoners' congress). Unzer Sztyme 1945;2:4-

57. Prezident fun Joint in Belzn (The President of Joint in Belsen). Unzer Sztyme 1946;6:22.

58. Trepman (Warschawski) P. Di yiddishe gimnazie in Bergen-Belzn (The Jewish high school in Bergen Belsen). Unzer Sztyme 1946;9:30.

59. Trepman P. Di kinder heym in Bergen-Belzn (The children's home in Bergen Belsen). Unzer Sztyme $1945 ; 5: 8$.

60. Vandalisher iberfal fun poilishe chuliganes oifn beishamedresh in Belzn (Vandalistic ambush by Polish hooligans on the synagogue in Belsen). Unæ2 Sztyme 1946;6:22.

61. Vaad Harabonim beim Z.K. fun di yidn in englisher zone (Rabbinical Committee at the Central Committee of Jews in the English Zonक्ळ. Unzer Sztyme 1946;6:22.

62. Koshere shchite in der englisher zone (Kosh slaughter in the English zone). Unzer Sztyn 1946;6:24.

63. B S. Eyropeishe konferents fun "Maccab" (European conference of "Maccabi"). Vochnble 1948;13(16): 3 .

64. Der farloif fun sport-yom-tov in yor-tog fun d $\frac{\bar{\alpha}}{\mathrm{q}}$ bafreiung (The course of the sport-festival on tise anniversary of the liberation). Unzer Sztyn 1946;10:23.

65. Feder Z. Bei der antshteiung fun yiddishn "Kazee Teyater" in Bergen-Belzn (On the rise of the Yiddis "Kazet Theatre" in Bergen Belsen). Unzer Sztyris 1946;9:37-38.

66. Brodetzki Z. Der kongres (The congress). Un Sztyme 1945;4:2-4

67. Editorial. Unzer Sztyme 1946;9:51.

68. Trepman P. "Efnt di toiern fun Belzn" (Open the gates of Belsen). Unzer Sztyme 1946;11:8-10.

69. Trepman P. "Unzer bafreiungs-yom-tov: a tog fun protest un tsorn!" (Our liberation festival: a day $\$ \$$ protest and fury!). Vochnblatt 1948;15(18):1.

70. Trepman P. Ha-atsomes ha-yeveyshes...: tsen yoळ noch der bafreiung fun Bergen Belzn (The dry bones...: ten years after the liberation of Berge $\vec{B}$ Belsen). Keneder Odler (Canadian Jewish Eagle $1955 ; 49(88): 2-4$

71. Cordell RF, Forsdick DH. Symposium commemoration of the liberation of the Bergen Belsen Concentration Camp and medic: management of disasters study period. FRAM 1999;145:28-30.

72. Vella EE. Belsen: medical aspects of a WW $\$$ concentration camp (letter). GRAMC 1984 130:200. 